SHORT COMMUNICATION

\title{
On the synonymy of Stictocephala alta (Walker) and Thelia constans Walker (Hemiptera: Membracidae)
}

\author{
Gabriel Simões de Andrade
}

Centro de Ciências Biológicas e da Saúde, Universidade Estadual do Oeste do Paraná. Rua Universitária 2069, Caixa Postal 711,85819-110 Cascavel, Paraná, Brasil.E-mail: gsandrade@unioeste.br

\begin{abstract}
This paper deals with the synonymy of Ceresa alta Walker, 1851, now Stictocephala alta, and its junior synonym, Thelia constans Walker, 1851. Notes on Stictocephala bisonia Kopp \& Yonke, 1977 are also presented.

KEY WORDS. Membracoidea; Ceresini; Smiliinae; systematics; taxonomy.

RESUMO. Sobre a sinonímia de Stictocephala alta (Walker) e Thelia constans Walker (Hemiptera: Membracidae). São abordadas a sinonímia de Ceresa alta Walker, 1851, atualmente Stictocephala alta, e de Thelia constans Walker, 1851, como seu sinônimo júnior. Comentários sobre Stictocephala bisonia Kopp \& Yonke, 1977 são apresentados também. PALAVRAS-CHAVE. Membracoidea; Ceresini; Smiliinae; sistemática; taxonomia.
\end{abstract}

\section{Stictocephala alta (Walker, 1851)}

Ceresa alta Walker, 1851: 529; Metcalf \& Wade, 1965: 844 (cat., = Smilia malina Germar, 1835); Broomfield, 1971: 331 (typ.); McKamey, 1998: 245 (cat., = Smilia malina Germar, 1835). Stictocephala alta; Andrade, 1997: 289 (comb. nov., syn.); Dietrich, Rothschild \& Deitz, 1999: 254 and 255 (not.).

Thelia constans Walker, 1851: 563; Broomfield, 1971: 342 (typ.). Syn. nov.

Dietrich et al. (1999) refuted the new combination of Ceresa alta Walker as Stictocephala alta (Walker) and its synonymy with Stictocephala bisonia Kopp \& Yonke, 1977, proposed by ANDRADE (1997), arguing among other facts that “...The holotype of Ceresa alta Walker is of ambiguous identity, being a female specimen from an unspecified locality...". The study of the female holotype of C. alta Walker, deposited in "The Natural History Museum" (London), and additional material identifiable also as $C$. alta and S. bisonia were done. They showed again that besides all the similar characters, the membrane of the tegmina corrugated and the post-ocular lobes compressed, which are synapomorphies for all the species of nearctic Ceresini with ornamentation of, at most, supra-humeral horns. This not leaving doubts about the procedence of the type of $C$. alta Walker from North America, although there is none information on the type and on the original description. Also, within all the species of Ceresini with the supra-humeral horns as only ornamentation, they are the only ones that are equaled in the size and other characters of the head, pronotum and tegmina.

Thus, although the synonymy of $C$. alta with $S$. bisonia stays unsolved, the placement of C. alta in Stictocephala is at least correct.
In addition to these studies, a close comparison of the female holotype of $C$. alta Walker with the female holotype of Thelia constans Walker, showed that they belongs to the same species.

On the other hand, Thelia constans; Caldwell, 1949 (p. 514, pl. 22), non Thelia constans Walker, 1851, appears in the catalog of Metcalf \& Wade (1965) as a species of Spissistilus Caldwell, but consulting to the work of CALDWELL (1949) it showed erroneous; it corresponds actually to Hadrophallus bubalus (Fabricius, 1794), which was published by ANDRADE (2005).

\section{ACKNOWLEDGMENTS}

I am indebted to Mick D. Webb (The Natural History Museum, London, UK), and also to Lewis L. Deitz and Robert L. Blinn (North Carolina State University, Raleigh, USA), by loan of material and additional assistance during my visits to the Institutions.

\section{LITERATURE CITED}

ANDrade, G.S. 1997. Stictocephala alta (Walker, 1851) sp. rev., comb. nov., the correct name for the "buffalo treehopper", with S. bisonia Kopp \& Yonke, 1977 as a new synonym, and notes on Hadrophallus bubalus (Fabricius, 1794) comb. nov. (Homoptera: Membracidae). Transactions of the American Entomological Society 123 (4): 289-295.

Andrade, G.S. 2005. Two synonyms for Hadrophallus bubalus (Fabricius) (Hemiptera, Membracidae). Revista Brasileira de Zoologia 22 (3): 819-820.

BRoomfield, P.S. 1971. A catalogue of the Membracid types (Homoptera: Membracidae) in the British Museum (Natural History). Bulletin of the British Museum of Natural

Revista Brasileira de Zoologia 25 (1): 148-149, March, 2008 
History (Entomology) 25 (8): 325-386.

Caldwell, J.S. 1949. A generic revision of the treehoppers of the tribe Ceresini in America north of Mexico, based on a study of the male genitalia. Proceedings of the United States National Museum 98: 491-521.

Dietrich, C.H.; M.J. Rothschild \& L.L. Deitz. 1999. Checklist and host plants of the treehoppers (Hemiptera: Membracidae) of North Carolina. Proceedings of the Entomological Society of Washington 101 (2): 242-262.

McKamey, S.H. 1998. Taxonomic catalogue of the Membracoidea
(Exclusive of Leafhoppers) - Second supplement to Fascicle 1 Membracidae of the General Catalogue of the Hemiptera. Memoirs of the American Entomological Institute 60: 1-377. MEtCALF, Z.P. \& V. WADE. 1965. General catalogue of the Homoptera. A supplement to Fascicle I - Membracidae of the General catalogue of Hemiptera. Membracoidea. In two sections. Raleigh, North Carolina State University, 1552p.

WALKER, F. 1851. List of the specimens of homopterous insects in the collection of the British Museum. London, vol. 2, p. 261-636.

Received in 27.III.2007; accepted in 13.II.2008. 